\title{
A CENTURY OF GLOBAL STOCK MARKETS
}

\author{
William N. Goetzmann \\ Philippe Jorion
}

Working Paper 5901

\author{
NATIONAL BUREAU OF ECONOMIC RESEARCH \\ 1050 Massachusetts Avenue \\ Cambridge, MA 02138 \\ January 1997
}

We thank seminar participants at the University of Michigan and Southern California for useful comments. Able research support was provided by Robin Brooks. This research received financial support from the Institute for Quantitative Research in Finance, for which we are grateful. This paper is part of NBER's research program in Asset Pricing. Any opinions expressed are those of the authors and not those of the National Bureau of Economic Research.

(C) 1997 by William N. Goetzmann and Philippe Jorion. All rights reserved. Short sections of text, not to exceed two paragraphs, may be quoted without explicit permission provided that full credit, including $\mathbb{C}$ notice, is given to the source. 


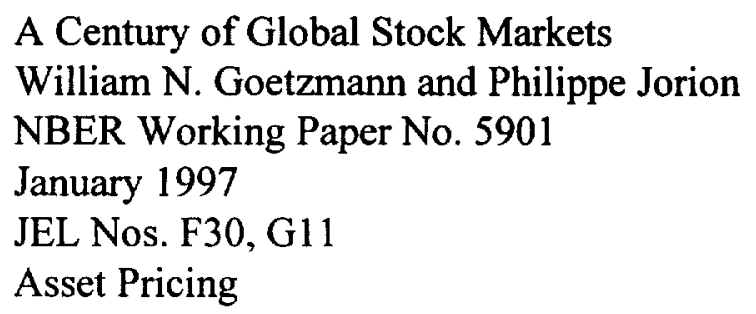

A Century of Global Stock Markets

William N. Goetzmann and Philippe Jorion

NBER Working Paper No. 5901

January 1997

JEL Nos. F30, G11

Asset Pricing

\begin{abstract}
The expected return on equity capital is possibly the most important driving factor in asset allocation decisions. Yet, the long-term estimates we typically use are derived from U.S. data only. There are reasons to suspect, however, that these estimates of return on capital are subject to survivorship, as the United States is arguably the most successful capitalist system in the world; most other countries have been plagued by political upheaval, war, and financial crises.

The purpose of this paper is to provide estimates of return on capital from long-term histories for world equity markets. By putting together a variety of sources, we collected a database of capital appreciation indexes for 39 markets with histories going as far back as the $1920 \mathrm{~s}$.

Our results are striking. We find that the United States has by far the highest uninterrupted real rate of appreciation of all countries, at about 5 percent annually. For other countries, the median real appreciation rate is about 1.5 percent. The high return premium obtained for U.S. equities therefore appears to be the exception rather than the rule.

Our global database also allows us to reconstruct monthly real and dollar-valued capital appreciation indices for global markets, providing further evidence of the benefits of international diversification.
\end{abstract}

William N. Goetzmann

Yale School of Management

Box 208200

New Haven, CT 06520-8200

and NBER

will@viking.som.yale.edu
Philippe Jorion

Graduate School of Management University of California at Irvine Irvine, CA 92697-3125

pjorion@uci.edu 


\section{Introduction}

In a now-famous article, Mehra and Prescott (1985) argue that standard general equilibrium models cannot explain the size of the risk premium on U.S. equities, which averaged about 6 percent over the 1889-1978 period. They show that one would need a very large coefficient of risk aversion, largely in excess of the usual value of 2 , to generate such a premium. This unsettling result has sparked a flurry of theoretical research which has explored alternative preference structures, including dropping the expected utility assumption and introducing habit formation. ${ }^{1}$ Such efforts, however, come at the cost of losing the intuition of standard models and have generally be viewed as unsuccessful. ${ }^{2}$

Rather than searching for preference structures that fit historical data, other explanations have focused on the limitations of the data. Rietz (1988) proposes a solution to the puzzle which involves infrequently occurring "crashes." Assuming a crash where output falls by 50 (or 25) percent of its value with a probability of $0.4 \%$ (or $1.4 \%$ ), Rietz generates "ex ante" equity premiums consistent with those observed in the U.S. and risk aversion of 5 (or 10).

A related argument is advanced in Brown, Goetzmann and Ross (1995), who claim that survival of the series imparts a bias to "ex post" returns. They show that an ex ante equity premium of zero can generate an ex post positive premium similar in magnitude to that observed for the U.S. market since 1926 by simply conditioning upon the market surviving an absorbing lower bound over the course of a century. ${ }^{3}$ The implication is that risk aversion cannot be inferred from the empirical analysis of historical data whose observation is conditional upon survival. While the Rietz argument leads to higher ex ante equity premiums, the survival argument points to biases in ex post premiums.

Unfortunately, these arguments are nearly impossible to sort out based on a century of U.S. equity data. Consider, for instance, a $0.4 \%$ annual probability of a large

\footnotetext{
${ }^{1}$ See Epstein and Zin (1991) for non-additive utility functions and Constantinides (1987) habit formation. Bansal and Coleman (1996) suggest that liquidity services provided by cash partly explain why returns on cash are so low.

${ }^{2}$ Burnside and McCurdy (1992) provide a good review of the equity premium puzzle.

${ }^{3} \mathrm{~A}$ similar argument is advanced by Goetzmann and Jorion (1996). They argue that many socalled "emerging markets" are in fact "re-emerging markets" as they have longer histories than commonly believed. Few analysts, however, bother to track the histories of markets that have disappeared.
} 
crash. We would then expect one crash to occur every 250 years. Even if we observed such a long sample series, our estimate of the crash probability would still be subject to enormous estimation error.

The only solution to this dilemma is to expand the sample by collecting additional cross-sectional data. In this paper, we reconstruct real capital appreciation series for equity markets in 39 countries over much of the twentieth century. We include not only those markets that survived, but also those markets which experienced both temporary and permanent interruptions. We use this new database to estimate the long-term returns to investing cross-sectionally in global markets over the twentieth century.

This paper provides the first comprehensive long-run estimates of return on equity capital across a broad range of markets. To date, virtually the only long-run evidence regarding equity rates of return is derived from the United States, for which we have continuous stock price history going back into the $1870 \mathrm{~s}^{4}$ We are able to augment the U.S. experience with a wide range of different global equity market histories.

We find striking evidence in support of the survival explanation for the equity risk premium. The U.S. had by far the highest uninterrupted real rate of appreciation, at about 5 percent annually. For most other countries, the median real appreciation rate was around 1.5 percent. This strongly suggests that estimates of equity premia obtained solely from the U.S. market are either biased upward by survivorship, or reflect fundamentally different investor expectations about risk across markets.

Beyond its potential value for shedding light on the equity premium puzzle, this global database allows a broad investigation into the behavior of equity markets over the very long run. We have been able to reconstruct the monthly real and dollar-valued capital appreciation for virtually all the equity markets that existed during the twentieth century. This enables us to examine markets in crisis as well as markets in peace and to compare the behavior of losing markets to the behavior of winning markets. We also construct global and non-U.S. indices which provide further evidence on the benefits of international diversification.

This paper is organized as follows. Section II motivates the search for differences in return on capital. Section III describes the construction of the global market

\footnotetext{
${ }^{4}$ For evidence on long-term U.S. data, see Goetzmann and Ibbotson (1994), Schwert (1990), Siegel (1992) and Wilson and Jones (1987). There is some long-term evidence from the U.K. markets, for instance, see Goetzmann (1993), Goetzmann and Jorion (1995) and DeLong and Grossman (1993).
} 
database. Section IV compares the performance of global stock markets and discusses biases affecting the construction of a global stock market index. Section $\mathrm{V}$ contains some concluding comments.

\section{The Importance of Compound Growth}

In September 1626, Pierre Minuit, the Governor of the West India Company, purchased Manhattan Island from the local Indians for the total sum of sixty guilders, or about twenty-four dollars. At first sight, this seems like the deal of the century.

Yet, slight differences in the time value of money over long horizons can result in vastly different conclusions. If one compounds this payment at a 5 percent rate of interest, it would have grown in 1995 to about 1.6 billion in current dollars, which seems expensive for 31 square miles of undeveloped land. Compounding at 3 percent, however, results in a much lower current price of $\$ 1.3$ million-a thousand-fold difference! This story shows that differences in rates of return on capital can lead to drastically different numbers when compounded over long horizons.

Our estimates of the rate of return on equity capital are typically based on a century of U.S. data, which reveals an equity premium of about 6 percent. As shown in this example, however, small differences in rates of return can have momentous implications over the long run. How much faith can we have in this number?

Not much, given the volatility of stock returns. Consider for instance a market which grows at a $6 \%$ annual rate with a standard deviation of $20 \%$. The question is, How many years do we require to establish that growth is positive with statistical confidence? Using the standard t-test at the $5 \%$ level, we require that

$$
t=\frac{\mu}{\sigma / \sqrt{N}}=\frac{0.06}{0.20 / \sqrt{N}}
$$

be greater than 2 . This requires $N$ to be at least greater than 44 years. In other words, we need about half a century of returns to be confident that this $6 \%$ equity premium is positive. Now, assume that the expected return is $3 \%$ instead. We now need more than 178 years of data to establish statistical significance!

Another problem is that we have reasons to suspect that estimates of return on capital from the United States are affected by survival. At the beginning of the century, active stock markets existed in a number of countries, including Russia, France, Germany, Japan, and Argentina. All of these markets have been interrupted for a 
number of reasons, including political turmoil, war, and hyperinflation. Assuming there was some probability of disruption for the U.S. market, this probability was not reflected in the observed data. In turn, this will bias our estimates of the equity premium.

As small differences in estimates on equity capital have dramatic implications for long-term growth, we feel it is important to extend our knowledge of equity premiums to a large cross-sectional sample of long-term data.

\section{A Global Stock Market Database}

The standard data sources on international stock prices are Morgan Stanley Capital International Perspectives (MSCIP) for developed markets and the International Finance Corporation (IFC) for emerging markets. Both are relatively recent.

MSCIP started to construct equity indices in January 1970 for a sample of 19 markets from industrial (developed) countries. These indices are built using a uniform methodology and include income and currency effects.

In 1980, the IFC tackled the issue of data collection and index construction for Emerging Markets (EMs), defined as those located in a developing country (using the World Bank classification.) The data base started in December 1980 with 9 márkets, which were backfilled to December 1975 and has expanded to 26 markets as of December 1995. The IFC collects share prices, dividend and other payments, and exchange rate information, which allows construction of a total return index that is consistent across all countries.

Beyond these databases, unfortunately, there is very little systematic information on the long-term performance of global stock markets. The United States is a rare exception, as monthly stock market indices have been constructed by Standard and Poor's and, prior to that, by Alfred Cowles (1939), going back into the 1870s. Instead, we turned to a variety of sources. The first is the International Monetary Fund, which publishes monthly stock price indices as reported by the local authorities in its International Financial Statistics (IFS) publication. The published indices generally represent monthly averages, as opposed to the MSCIP and IFC data, and do not include dividends. The IMF also publishes price indices and exchange rates, which will be used to compute real returns and dollar returns. We used the Wholesale Price Index (WPI) to deflate nominal returns, whenever available. The WPI measure offers 
a number of advantages. WPI indices generally have longer histories than consumer indices, are less affected by differences in domestic consumption patterns, and are more responsive to monetary disturbances than other inflation measures. ${ }^{5}$

The first IFS publication was issued in 1948. Prior to the IMF, our source is the League of Nations (LN), which collected data on the capital appreciation of market indices in the period from 1929 through 1944 . This collection effort was bridged by the United Nations from 1945 to 1948. Finally, the International Abstract of Economic Statistics publications have stock market data going back to 1919.

By patching together data from these sources, we are able to reconstruct histories for a number of stock markets going back to the early 1920s. This was a painstaking effort, because of erratic data reporting. The IMF, for instance, provides a CD-ROM with data starting in 1957. Unfortunately, this database suffer from sample selection biases, as a number of markets that were followed in the 1960s are not contained in the CD-ROM. Data for these markets had to be collected from the IFS monthly publications. More recent EM data, when not available from the IFS publication, are taken directly from the IFC database. ${ }^{6}$

In order to minimize survivorship biases, we follow all markets that were reported by these publications at any point during the 1929 to 1970 period. After 1970 , a flurry of new markets opened (or re-opened). These emerging markets, however, have relatively short histories and have already been extensively analyzed. We obtain a total of 39 markets. ${ }^{7}$

Whenever data sources do not overlap, we attempt to link series by comparing annual averages. This is the case for Austria, for instance, whose price history was interrupted by the Anschluss (German annexation) in April 1938. The UN publication, fortunately, provides annual averages from 1946 on and going back to 1935 . We are therefore able to reconstruct a long-term history for Austria, albeit with an 8-year gap during the war.

Initially, we began by collecting annual data, but then we found the monthly data to be of much better quality and allowed cleaner linkages between various sources.

\footnotetext{
${ }^{5}$ There were a few instances where we had to use Consumer Price Index data (e.g., post-1947 data for Belgium, France, New Zealand, Peru, and Israel.)

${ }^{6}$ The measurement of exchange rates also proved quite difficult. The League of Nations, for instance, reports rates in percentage of their 1929 gold parity value, from which current spot rates relative to the dollar had to be reconstructed. Many currencies also changed units or denomination during this century.

${ }^{7}$ The only market we deliberately omit is Lebanon, which we could not find inflation data.
} 
We also found that monthly data was more accurate and informative than annual data, as it allowed us to perform event studies centered around specific months.

Note that, despite all our efforts, this database is still not free from selection biases. The first type of bias occurs when backfilling of an index uses only stocks that are in existence at the end of the sample. In the case of Austria, for instance, even though the stock market has recovered, some companies may have fared badly or disappeared during the war. Therefore, a selection bias is induced if these companies are not included in the index.

The second type of remaining bias is much more serious. For some markets, we were unable to link gaps. In particular, there appears to be no link between stock market prices of Germany and Japan before and after the war. As these two countries did not fare too well during these gaps, it is fair to surmise that we are missing important negative information in the series. We will describe later how this problem was handled.

\section{Empirical Analysis}

\section{IV.1 Performance of Global Stock Markets}

We calculated returns using three different numeraires: the local currency, a real price index, and the dollar. Because of wide differences in inflation across time and country, we primarily focus on WPI-deflated returns. Returns in dollars as a common currency should give similar results over the long run if exchange rates move in line with inflation differentials, i.e. if Purchasing Power Parity holds. Differences between real and dollar returns, however, may be induced when exchange rates are pegged by central banks at artificial levels.

Table 1 presents compound (geometric) returns for 39 markets, grouped by regions. These results are striking. Of the sample of 39 countries, real returns are the highest for the United States, at $4.73 \%$ per annum. There is not a single country with a higher return over the total period. Therefore, the high U.S. equity premium seems to be the exception rather than the rule.

These results are perhaps better visualized in Figure 1, which plots the compound each return for each market against its observed life. Longer lives lead to more precise, less volatile, estimates of expected returns. Moving to the right of the figure, we observe that the U.S. market has the highest realized return of all markets. 
The bottom of Table 1 shows average and median returns for all countries, as well as for a group of countries for which we have data going to the 1920s. The median real returns for all 39 countries was $1.5 \%$; the median returns for countries with long histories was $2.1 \%$. These results strongly suggest that the $4.73 \%$ return for the United States was highly unusual. As it was also one of the few series without any break, this high return could be ascribed to survival.

Other high returns, however, are obtained in some cases. For instance, Germany experienced a steep run-up in prices over the period 1950 to 1995 . But this $5.74 \%$ return must be offset against mediocre growth before the war, and an unknown performance from 1944 to 1950 . Similarly, Japan returned a real return of $5.79 \%$ after the War, but much lower returns from 1921 till 1944. Other markets that gapped, such as Portugal, Chile, and Peru, also did well recently, but not so well when going back further in time. These are typical of re-emerging markets, whose recent performance appears to be, on the surface, nothing short of stellar. What our analysis shows is that the performance of the same markets has also been appalling at other times.

Next, Table 2 presents conventional measures of average (arithmetic) capital appreciation returns and standard deviations, converted to an annual basis. ${ }^{8}$ Data are presented in the local currency and in real terms. The table shows that the $16.5 \%$ volatility of the U.S. market is not particularly high when compared with other stock markets. Therefore the high return obtained in the U.S. does not seem to compensate for higher risk as measured by volatility.

The table also reports the results from standard statistical tests of significance of the real capital appreciation return premium. At the $99 \%$ level, we can only reject the hypothesis of a zero long-run appreciation return for the U.S. and Sweden, two markets notable for avoiding war and economic upheaval. Over shorter periods, significantly positive returns are obtained for Germany and Japan after the war. When averaged with pre-war data, however, these returns look less impressive.

Another notable feature of Tables 1 and 2 is that, for markets that have long histories, the range of average returns is quite narrow. We have about 75 years of data for the U.S., Canada, and most of Europe. Across all of these markets, real growth has ranged from a low of $-2.23 \%$ (for Spain) to a high of $4.73 \%$ (for the

\footnotetext{
${ }^{8}$ Since price data are monthly averages, all the standard deviations are lower than from using month-end data. In addition, averaging induces spurious positive autocorrelation in the return series.
} 
US). Nine of these markets have growth rates grouped between 1 and 3 percent, an astonishingly narrow range considering the imprecision with which average returns are measured.

\section{IV.2 The Effect of Dividend Omission}

The previous section has displayed striking results: long-term returns on the U.S. stock market appear to be greater than those of any other market. One question that arises is whether this result could be due to the omission of dividends. To shed light on this issue, Table 3 presents performance numbers for the more recent MSCIP indices, which mainly cover industrial countries.

The tables display compound real returns, with and without reinvestment of dividends. The difference due to the omission of dividends is shown in the third column. The fourth column reports the average level of inflation.

Presumably, the results in the previous section could simply reflect a bias due to the omission of dividends. For this bias to be effective, other markets must systematically display a higher income component of return than the US. Table 3 clearly shows that this is not the case. The U.S. income return is $4.14 \%$, which is quite close to the group average of $4.25 \%$. Therefore, there is no indication that the high return obtained by the U.S. over the last 65 years is due to dividend bias. If anything, the bias is in the opposite direction. Japanese equities, which by now constitute the largest non-U.S. market, paid an income return of $1.84 \%$ over the last 25 years, which is much lower than that of U.S. equities.

The bottom of the table reports the only long-term data with dividend that we are aware of. ${ }^{9}$ To maintain comparability with the original data sources, we have used the Consumer Price Index (CPI) to deflate returns, except for Denmark where the WPI is employed. Including dividends, the U.S. displays the highest real equity returns. Britain, another long-term survivor, is a close second; other markets have returns lower by 109 to 334 basis points. Therefore, there is no evidence that the performance of U.S. equities are artificially high because of relatively low US dividend payments.

\footnotetext{
${ }^{9}$ Data sources are as follows. For the U.S. market, Ibbotson (1995) and prior to that, Cowles (1939); for the UK, Barclays deZoete Wedd (1993); for Switzerland, Wydler (1989); for Sweden, Frenneberg and Hansson (1992); and for Denmark, Timmerman (1992). All of the data have been updated to 1995 using the MSCIP indices.
} 


\section{IV.3 Evidence on the Equity Premium Puzzle}

The data we present thus far does not explicitly "solve" the equity premium puzzle, as theoretically formulated. Strictly speaking, the equity premium puzzle concerns the spread of expected total return on a single, risky security in an economy over the return of a riskless security. Siegel (1995) points out that defaults on "riskless" government securities have often occurred in periods of global stress-which of course raises the question of what the riskless asset might actually be and whether the stylized, single economy, two-asset formulation of the equity premium puzzle is robust.

In the absence of a riskless asset which is immune to the crisis events imagined by Rietz (1988), it seems reasonable to substitute physical storage of goods (i.e. inflation rates for $\mathrm{T}$-bill rates). In this case, using real returns as a proxy for the equity premium clearly supports the hypothesis that the ex post observed U.S. premium is higher because the U.S. was a winner. This evidence, in turn, is consistent with the "survival" hypothesis suggesting that the magnitude ex post observed equity returns may be higher than their ex ante expectation.

Is there any evidence in the data supporting the Rietz (1988) hypothesis that the ex ante equity premium is as high we observe ex post? The issue is whether there was some probability of the U.S. market experiencing a large crash. In fact, this problem is akin to the "peso problem" in the foreign exchange market, where forward rates appear to be systematically biased forecasts of future spot rates, essentially because they account for a non-zero probability of devaluation that may not be observed in the test sample period. More generally, peso problems can be interpreted as a failure of the paradigm of rational expectations econometrics, which requires that the ex post distribution of endogenous variables be a good approximation to the ex ante distribution that agents think may happen. The failure may not be that of the economic agent, but that of the econometrician, who only analyzes series with continuous histories. Unusual events with a low probability of occurrence but severe effects on prices, such as wars or nationalizations, are not likely to be well represented in samples and may be totally omitted from survived series.

Our cross-sectional data provides evidence about major market crashes not present in U.S. data. We have a sample of 21 markets for which we have data in the 1920 s. Out of these, only six experienced no interruption in the last 75 years (the U.S., Canada, the U.K, New Zealand, Sweden, and Switzerland). Eight experienced a 
temporary suspension of trading. The seven remaining markets suffered a long-term closure. Even though these events are not independent, they indicate that market failure is not a remote possibility.

While it is entirely possible that the magnitude of the observed equity premium is due both to survival bias and to the "pricing" of an infrequently occurring crash, it is difficult to believe that the ex ante premium for the U.S. should be higher than for other markets. If past crash frequency is any indication of future crash probability, then the Rietz (1988) hypothesis would suggest that markets with more interruptions should have a higher equity premium. If we believe that the magnitude of the equity premia for each country is related to the ex post historical real appreciation, then the opposite appears to be the case. Absent survival effects, the Rietz (1988) hypothesis is inconsistent with cross-sectional differences in historical global equity market returns. In the next section, we investigate the possibility that markets anticipate major crashes.

\section{IV.4 Disappearance as an Event}

To understand how risk premiums respond to the probability of major market crashes, we can examine the behavior of markets around interruptions. Sample selection of markets will create a bias if the performance of markets that are interrupted is systematically poor before the break. By the same token, falling stock prices prior to a market break may be indicative of investor assessment of increasing probability that the market will fail.

To test this hypothesis, we adopt the event-study methodology by constructing an equally-weighted index where real returns are aligned on the interruption date. The advantage of this "portfolio" approach is that it fully accounts for cross-correlation between events, which may be substantial if markets disappear due to global events.

We identified a sample of 25 breaks for which data was clearly interrupted. Table 4 identifies each of these events. Many were of a global nature, such as the Second World War, or the depression of the early 1930s. A number of events, however, were country-specific.

Figure 2 plots the time-series of the portfolio value, starting one year before the break. It shows prices falling by $21 \%$ relative to their peak, on average. However, large, this fall of $21 \%$ in real terms understates the true loss of value to equities. During the War, in particular, prices were kept artificially high through prices controls; 
these prices do not represent transaction prices as liquidity dried up. ${ }^{10}$

Eventually, reality "kicked" in. Figure 3 compares the performance of markets sorted by country involvement during the war. As the figure shows, the advent of the war led to a sharp fall of about $20 \%$ in the value of equities of Allied countries (including the US, Canada, the UK and Commonwealth countries) for the next two months. A similar fall was suffered by neutral countries (Sweden and Switzerland). The index for occupied countries, ${ }^{11}$ in contrast, registered steady gains, which were only wiped out later as stock prices started to reflect transaction prices and as inflation became apparent. Five years later, the index moved below that of Allied countries, as we would have expected. In reality, the index should have been even lower if we had accounted for those markets that disappeared in the process (such as Germany, Hungary, and Czechoslovakia.)

Table 4 also details the performance around each individual break. All markets suffered a substantial drop before the break, reaching $69 \%$ for Argentina. One exception was Poland, which experienced a slight price increase, possibly because the series was stopped in July, three months before Poland was invaded, or because the advent of the war was unanticipated (as testified, for example, by the level of preparedness of the French military). The price drops in Germany and occupied Europe were also unusual, as explained before, for artificial reasons. In all other cases, the event creating the market closure was anticipated.

In eleven of these cases, the equity series are interrupted without restarting later (or there is no continuous series spanning the interruption). These cases include Germany, Japan, Eastern European countries taken over by the Soviet Union, Greece, Egypt, Chile, Argentina, and Portugal. Some of these were the result of a foreign occupation and widespread destruction due to war. In Egypt and Chile, the state took control of the economy. These are precisely the situations where we would expect equities to fare most badly. Unfortunately, we do not have price information for these

\footnotetext{
${ }^{10}$ In Germany, Italy, and German-occupied territories, dealing in shares were subject to strict controls, ranging from taxes on profits and capital gains to the rationing of purchases and to the compulsory declaration of securities holdings. In June 1942, for instance, the sale of German shares became prohibited, unless they were first offered to the Reichsbank. The Reichbank had the option to buy them at December 1941 prices in exchange for bonds that remained in the bank's possession. It is no wonder that this confiscatory system led to a sharp fall in trading activity. There were also rigid price controls in Japan during the war. Therefore many of these price indices do not represent market-determined prices.

${ }^{11}$ This sample includes Belgium, Czechoslovakia, France, Denmark, Finland, Germany, Hungary, Italy, Netherlands, and Norway.
} 
breaks.

One exception is the Portuguese stock market, which closed in April 1974 as a military junta took over the country, and reopened in March 1977, then traded intermittently. Going back to Portuguese Central Bank statistics, we were able to link the stock price series, which suffered a fall of $86 \%$ in real terms during the interruption in trading. We surmise that other markets have also fared badly, but that these performance numbers unfortunately disappear from the history of global stock markets.

Going back to Figure 2, we have separated markets that were temporarily interrupted from those that disappeared, or "died" later. Markets that became extinct dropped by $27 \%$ the year before the break; markets that subsequently recovered dropped by $16 \%$ only before the break. To the extent that the event causing the break was anticipated, the market seems to have been able to gauge the gravity of unfolding events. Price declines before breaks is consistent with increasing demand for risk compensation for a catastrophic event.

\section{IV.5 A Global Stock Index}

The global equity data provide a unique opportunity to construct a global equity index - an index which, for the first time includes defunct as well as surviving countries and extends back 75 years. Because we have no data on market capitalization going back that far, we assign weights based on Gross Domestic Product. Annual GDP information was obtained from Mitchell $(1992,1993,1995)$ and converted to U.S. dollars using annual averages. At the beginning of each decade, we construct a crosssection of national GDPs, which are used to construct weights. From these weights we build a global stock index for the following ten years.

Table 5 presents the GDP weights at three points in time, 1920, 1950, and 1990. The table reveals a number of interesting observations. The United States accounted for about half of the world's output until the 1950s; the proportion has since declined to about 30 percent. This decline is due to faster growth in other countries such as Japan and Germany. Japan, in particular, has zoomed from $4 \%$ of world GDP to $16 \%$ during this century, even after dipping below $2 \%$ after the war.

The GDP-based weights can be compared to stock market capitalization-based weights, which are reported in the last column. We observe that the stock market capitalization percentages of the U.S., the UK, Japan and South Africa are generally 
greater than that of other countries. Continental Europe, for instance, has had a history of relying on bank lending rather than raising funds through capital issues. Overall, however, the GDP weights are roughly of the same order of magnitude as market weights.

Our goal is to construct a long-term history of stock markets that best represents the investment opportunities investors would have faced throughout these years. Still, biases can be introduced in the measured performance in a number of ways. The first is backfilling, and the second is due to interruptions. There is not much the researcher can do about backfilling if the series are the only ones available. As for interruptions, the problem is that data before the interruption are commonly ignored. Interruptions can be of two types: temporary closure of an exchange, with the series starting again later, or permanent interruption of these series, with no information about the continuity of prices across the interruption.

We take a number of different approaches to the construction of the global index: (i) our "survived" index includes all markets since the last interruption, which can either be a temporary break, or major interruption,

(ii) our "continuous" index includes all markets for which we have observations, linking series across temporary closures; markets which suffer permanent interruptions, however, are skipped,

(iii) our "reconstructed" index attempts to fill in series which experience a major interruption.

We expect the bias to decrease as we move from (i) to (iii). The difficult part is to estimate market losses during a permanent interruption such as war or nationalization. We have eleven occurrences of permanent breaks (or "deaths") out of our sample of 39 markets. For Germany, for instance, the series stops in August 1944 at the conclusion of the Second War. Even if we take into account, under approach (ii), the decline in prices preceding the stop, we should recognize that investors in German equities will have fared badly throughout these times.

As a benchmark, the total fall in value of French equities from 1940 to 1949 amounted to $38 \%$ (not annualized), measured in dollars. This is quite a large loss, especially one considers that U.S. equities returned a total of $20 \%$ over the same period. We therefore arbitrarily imputed a charge of $50 \%$ of the value of equities to a permanent series interruption. In other words, when a series experiences a permanent break, we assume that the value of the market fell by $50 \%$ the following month. Table 
6 presents the performance of the various global stock indices. Over the last 75 years, the U.S. stock market provided an arithmetic capital return of $5.98 \%$, with a volatility of $16.5 \%$, both measured in real terms. Figure 4 plots the performance of the U.S., global, and non-U.S. indices (using the continuous series).

The wide differences in the performance of the global indices point to the importance of accounting for losing markets. The "survived market" index has an average return of $5.35 \%$; it only account for markets since their last break. The "continuous market" index has an average return of $4.86 \%$; it accounts for all markets when available. The "reconstructed market" index has an average return of $4.74 \%$; it assumes that markets that fail lose $50 \%$ of their value. Going from the first to the third estimate should move us closer to a true, unbiased, measure of long-term return. This suggests survival biases on the order of 60 basis points, which is quite substantial when accumulated over 75 years. ${ }^{12}$

Table 6 also shows that a Non-U.S. stock market index, based on "continuous markets" would have returned an arithmetic average of $3.51 \%$, which is a full 247 basis points below that of U.S. equities. The difference between the "survived" and "reconstructed" Non-U.S. indices, which can be used as a measure of survival bias, amounts to $4.17 \%-3.29 \%$, or 88 basis points.

Table 7 presents similar data, measured in U.S. dollars. The dollar return on U.S. equities was $8.54 \%$. That on the global index was $8.48 \%, 8.09 \%$, and $7.96 \%$, using the three respective approaches. Similarly, the average return on the non-U.S. index was $7.60 \%, 7.23 \%$, and $6.99 \%$. Again the survival bias is on the order of 60 basis points.

The tables also allow us to compare the performance of U.S. equities with that of non-U.S. markets. Focusing first on continuous non-U.S. index measured in real terms, the performance shortfall was 247 basis points relative to the U.S. market. We also measured t-statistics for the differences in expected returns between U.S. and Non-U.S. markets. The t-values for the three indices are $1.15,1.52$, and 1.65 , with only the last one significant at the 10 percent level. Turning next to dollar-valued data, the performance shortfall of the continuous non-U.S. index, was 131 basis points relative to the U.S. market. ${ }^{13}$

\footnotetext{
${ }^{12}$ In addition, we could argue that the fact that the U.S. accounts for 30 to $50 \%$ of the index, combined with the fact that it is one of the few markets with a continuous history, lessens the effect of survival. We would expect biases to be greater with an equally-weighted index, for instance.

${ }^{13} \mathrm{~T}$-statistics for the differences in expected returns between U.S. and Non-U.S. markets are 0.57 , 0.78 , and 0.92 , which is not statistically significant at conventional levels.
} 
To understand the momentous implications of these differences in long-term rates of return, consider the following experiment. First, let us record the current capitalization of non-U.S. equity markets, which was about $\$ 9,000$ billion by the end of 1995. These markets have grown at an average rate of $2.92 \%$, which is less than the $4.73 \%$ growth rate for the US. Going back to 1921 , this implies that the market capitalization of non-U.S. equities was $\$ 9,000$ billion divided by $(1+2.92 \%)$ to the power of 75 , which amounts to $\$ 1,040$ billion in current dollars.

Next, assume that all markets had grown at the U.S. rate of growth. The market value of these equities would then be $\$ 980$ billion times $(1+4.73 \%)$ to the power of 75 , which amounts to $\$ 33,270$ billion. In other words, the opportunity cost of growing at about $3 \%$ instead of the $5 \%$ U.S. clip was $\$ 24,270$ billion in today's dollars. If the difference in growth rates was only $1 \%$, as opposed to the $1.75 \%$ above, the difference would still be $\$ 9,590$ billion. In other words, foreign markets would be double their current size if they had grown only $1 \%$ faster than what they did!

Finally, Tables 6 and 7 also provide estimates of the volatility of the various indices. The volatility of all three global indices is lower than that of the U.S. market alone, reflecting the fact that the portfolio is spread over a greater number of markets. Over the last 75 years, the correlation coefficient between real returns on the U.S. index and on the continuous Non-U.S. index was 0.528 ; that measured in dollars was virtually identical, at 0.521 . These low correlations provide further support for the risk reduction benefits from going international. 


\section{Conclusion}

"Financial archaeology" involves digging through reams of financial data in search for answers. Sometimes this involves relying upon poor quality data to draw inferences about markets in states of crisis. Even so, these data provide invaluable information to help understand long-term histories of capital markets.

We feel it is important to learn from history. This is especially true in view of the current rush toward emerging markets which is largely driven by their recent sizzling performance. This is why paper paints a broad picture of the performance of global stock markets over a century (well, almost).

The main lesson from our unique long-term data is that global capital markets have been systematically subject to dramatic changes over this century. Major disruptions have afflicted nearly all the markets in our sample, with the exception of a few such as the United States. Markets have been closed or suspended due to financial crises, wars, expropriations, or political upheaval.

No doubt this explains our finding that the 5 percent real capital appreciation return on U.S. stocks is rather exceptional, as other markets typically have returned 3 percent less than U.S. equities. These empirical results provide support for the hypothesis that the equity premium puzzle is due to conditioning estimates upon the best performing market.

Whether similar disruptions will happen again is an open question. By now, however, it should be clear that if we fail to account for the "losers" as well as the "winners" in global equity markets, we are providing a biased view of history which ignores important information about actual investment risk. 


\section{References}

Bansal, Ravi and Wilbur Coleman, 1996, "A Monetary Explanation of the Equity Premium, Term Premium, and Risk-Free Rate Puzzles," Journal of Political Economy 104, 1135-1171.

Barclays de Zoete Wedd, 1993, The BZW Equity $\mathcal{E}^{3}$ Gilt Study: Investment in the London Stock Market since 1918, Barclays deZoete Wedd: London: United Kingdom.

Brown, Stephen, William Goetzmann and Stephen Ross, 1995, "Survival," Journal of Finance 50, 853-873.

Burnside, Craig and Thomas McCurdy, 1992, "The Equity Premium Puzzle," in The New Palgrave Dictionary of Money and Finance, edited by P. Newman, M. Milgate, and J. Eatwell, New York: Stockton Press.

Constandinides, George, 1987, "Habit Formation: A resolution of the Equity Premium Puzzle," Journal of Political Economy 98, 519-543.

Cowles, Alfred, 1939, Common Stock Indices, 1871-1937, Cowles commission for research in economics, Monograph no. 3., Principia Press: Bloomington, Ind.

Epstein, Larry and Stanley Zin, 1991, "Substitution, Risk Aversion and the Temporal Behaviour of Consumption and Asset Returns: An Empirical Investigation," Journal of Political Economy 99, 263-286.

Frenneberg, Per and Bjorn Hansson, 1992, "Swedish Stocks, Bonds, Bills, and Inflation (1919-1990)," Applied Financial Economics 2, 79-86.

Goetzmann, William, 1993, "Patterns in Three Centuries of Stock Market Prices," Journal of Business 66, 249-270.

Goetzmann, William and Roger Ibbotson, 1994, "An Emerging Market, the New York Stock Exchange 1816-1872," Journal of Business 68, 483-508.

Goetzmann, William and Philippe Jorion, 1996, "Re-emerging Markets," Yale University, mimeo.

Goetzmann, William and Philippe Jorion, 1995, "A Longer Look at Dividend Yields," Journal of Business 68 (October), 483-508.

Ibbotson, R., 1995, Stocks, Bonds, Bills, and Inflation: 1995 Yearbook, Ibbotson Associates: Chicago, IL.

International Conference of Economic Services, 1934, International Abstract of Economic Statistics, ICES: London, United Kingdom.

International Statistical Institute, Permanent Office, 1938, International Abstract of Economic Statistics, ICES: The Hague, The Netherlands. 
International Finance Corporation, 1995, The IFC Indexes: Methodology, Definitions, and Practices, IFC: Washington, DC.

International Monetary Fund, various issues, International Financial Statistics, IMF: Washington, DC.

League of Nations, various issues, Statistical Yearbook, LN: Geneva, Switzerland.

Mehra, Rajnish and Edward Prescott, 1985, "The Equity Premium: A Puzzle," Journal of Monetary Economics 15 (March), 145-161.

Mehra, Rajnish and Edward Prescott, 1988, "The Equity Premium: A Puzzle?," Journal of Monetary Economics 22 (July), 133-136.

Mitchell, Brian, 1995, International Historical Statistics: Africa, Asia 81 Oceania, 1750-1988, Stockton Press: New York, NY.

Mitchell, Brian, 1993, International Historical Statistics: The Americas 17501988, Stockton Press: New York, NY.

Mitchell, Brian, 1992, International Historical Statistics: Europe, 1750-1988, Stockton Press: New York, NY.

Rietz, Thomas, 1.988, "The Equity Premium: A Solution," Journal of Monetary Economics 22 (July), 117-131.

Schwert, Bill, 1990, "Indexes of U.S. Stock Prices from 1802 to 1987," The Journal of Business 63 (July), 399-426.

Siegel, Jeremy, 1992, "The Equity Premium: Stock and Bond Returns Since 1802," Financial Analysts Journal 48 (January), 28-38.

Siegel, Jeremy, 1994, Stocks For the Long Term, Richard D. Irwin: New York, NY.

Timmerman, Allan, 1992, "Changes in Danish Stock Prices 1914-1990," Nationalokonomisk Tidsskrift 130, 473-482.

United Nations, various issues, Monthly Bulletin of Statistics, UN: New York, NY.

Wilson, Jack and Charles Jones, 1987, "A Comparison of Annual Common Stock Returns," The Journal of Business 60, 239-258.

Wydler, Daniel, 1989, "Swiss Stocks, Bonds, and Inflation: 1926-1987," Journal of Portfolio Management (Winter) 15, 27-32. 
Table 1

Long-Term Performance of Global Equity Markets

Compound Return in Percent per Annum

\begin{tabular}{|c|c|c|c|c|c|}
\hline Country & Poriod & $\begin{array}{r}\text { Iominal } \\
\text { Return }\end{array}$ & $\begin{array}{r}\text { Real } \\
\text { Return }\end{array}$ & $\begin{array}{l}\text { Dollar } \\
\text { Return }\end{array}$ & Inflation \\
\hline U.S. & $1 / 21-12 / 95$ & 7.37 & 4.73 & 7.37 & 2.57 \\
\hline Canada & $1 / 21-12 / 95$ & 5.51 & 2.77 & 5.07 & 2.67 \\
\hline Austria & $1 / 25-12 / 95$ & 5.57 & 1.52 & 5.04 & 3.99 \\
\hline Belgium & $1 / 21-12 / 95$ & 4.25 & -0.54 & 3.30 & 4.82 \\
\hline Denmark & $1 / 26-12 / 95$ & 5.52 & 1.49 & 4.94 & 3.98 \\
\hline Finland & $1 / 31-12 / 95$ & 10.21 & 1.94 & 6.21 & 8.10 \\
\hline France & $1 / 21-12 / 95$ & 8.74 & 0.33 & 3.81 & 8.38 \\
\hline $\begin{array}{r}\text { Germany+ } \\
\text { Germany }\end{array}$ & $\begin{array}{c}24-95 \\
1 / 24-7 / 44\end{array}$ & $\begin{array}{l}5.82 \\
(0.82)\end{array}$ & $\begin{array}{l}4.46 \\
(1.65)\end{array}$ & $\begin{array}{l}8.49 \\
(3.40)\end{array}$ & $\begin{array}{c}1.39 \\
(-0.82)\end{array}$ \\
\hline Germany & $1 / 60-12 / 95$ & $(8.27)$ & $(5.74)$ & $(10.84)$ & $(2.39)$ \\
\hline Ireland & $1 / 34-12 / 95$ & 6.77 & 1.13 & 4.81 & 5.57 \\
\hline Italy & $1 / 28-12 / 95$ & 10.04 & -0.01 & 3.01 & 10.05 \\
\hline Netherlands & $1 / 21-12 / 95$ & 4.15 & 1.98 & 5.44 & 2.12 \\
\hline Norvay & $1 / 28-12 / 95$ & 6.84 & 2.60 & 6.02 & 4.13 \\
\hline Portugal+ & $30-95$ & 8.24 & 2.25 & 6.55 & 5.86 \\
\hline Portugal & $12 / 30-4 / 74$ & $(5.21)$ & $(1.16)$ & $(4.96)$ & $(4.00)$ \\
\hline Portugal & $1 / 82-12 / 95$ & $(18.24)$ & $(5.72)$ & $(11.65)$ & $(11.84)$ \\
\hline Spain & $1 / 21-12 / 95$ & 4.35 & -2.23 & 1.56 & 6.73 \\
\hline Sreden & $1 / 21-12 / 95$ & 7.04 & 3.71 & 6.56 & 3.22 \\
\hline Switzerland & $1 / 26-12 / 95$ & 4.67 & 3.03 & 6.95 & 1.59 \\
\hline UK & $1 / 21-12 / 95$ & 6.26 & 2.28 & 1.97 & 3.89 \\
\hline Czechoslovakia & $1 / 21-6 / 43$ & 4.70 & 4.39 & HA & 0.29 \\
\hline Greece & $7 / 29-9 / 40$ & -2.12 & -5.50 & -8.08 & 3.58 \\
\hline Bungary & $1 / 25-6 / 44$ & 6.29 & 2.80 & $\mathbf{H A}$ & 3.40 \\
\hline Poland & $1 / 21-6 / 39$ & -6.90 & -2.97 & -3.77 & -3.33 \\
\hline Romania & $12 / 37-6 / 41$ & -5.36 & -28.06 & -14.64 & 31.55 \\
\hline Australia & $1 / 31-12 / 95$ & 7.06 & 1.50 & 6.38 & 5.48 \\
\hline Yer Zealand & $1 / 25-12 / 95$ & 5.65 & -0.47 & 3.63 & 6.14 \\
\hline Japant & $21-95$ & 6.08 & 3.69 & 6.88 & 2.30 \\
\hline Japan & $1 / 21-5 / 44$ & $(1.23)$ & $(-0.34)$ & $(-1.83)$ & $(1.58)$ \\
\hline Japan & $4 / 49-12 / 95$ & $(8.62)$ & $(5.79)$ & $(11.57)$ & $(2.67)$ \\
\hline India & $1 / 40-12 / 95$ & 5.44 & -2.01 & 1.09 & 7.61 \\
\hline Pakistan & $7 / 60-12 / 85$ & 7.79 & -1.62 & 1.97 & 7.93 \\
\hline Philippines & $7 / 54-12 / 95$ & 5.64 & 0.96 & -0.72 & 10.15 \\
\hline
\end{tabular}




\begin{tabular}{|c|c|c|c|c|c|}
\hline Argentinat & $47-95$ & 89.17 & -5.36 & -2.03 & 99.88 \\
\hline Argontina & $9 / 47-7 / 65$ & $(-5.78)$ & $(-25.09)$ & $(-23.64)$ & $(25.78)$ \\
\hline Argontina & $12 / 75-12 / 95$ & $(254.25)$ & $(16.81)$ & $(22.61)$ & (203.26) \\
\hline Brazil & $2 / 61-12 / 95$ & 146.21 & -0.90 & 4.02 & 153.26 \\
\hline Mexico & $12 / 34-12 / 95$ & 20.12 & 2.40 & 5.96 & 17.31 \\
\hline Chilet & $27-95$ & 25.04 & -2.13 & 0.64 & 27.76 \\
\hline Chile & $1 / 27-3 / 71$ & $(12.98)$ & $(-5.37)$ & $(-4.23)$ & $(19.39)$ \\
\hline Chile & $12 / 73-12 / 95$ & $(52.81)$ & $(4.61)$ & $(11.01)$ & $(46.08)$ \\
\hline Colombia & $12 / 36-12 / 95$ & 10.12 & -4.32 & -1.05 & 15.09 \\
\hline Perut & $41-95$ & 36.17 & -3.71 & 5.06 & 41.41 \\
\hline Poru & $3 / 41-1 / 53$ & $(2.19)$ & $(-11.69)$ & $(2.19)$ & (15.71) \\
\hline Peru & $1 / 57-12 / 77$ & (1.72) & $(-9.71)$ & $(-7.24)$ & $(12.66)$ \\
\hline Peru & $12 / 88-12 / 95$ & $(434.33)$ & $(35.50)$ & $(60.06)$ & (294.33) \\
\hline Uruguay & $12 / 36-11 / 44$ & 6.27 & 2.41 & $\boldsymbol{H A}$ & 3.77 \\
\hline Venezuela & $12 / 37-12 / 95$ & 7.92 & -2.60 & -0.13 & 10.80 \\
\hline Egypt & $7 / 50-9 / 62$ & -1.45 & -2.82 & -1.62 & 1.41 \\
\hline Israel & $1 / 57-12 / 95$ & 38.28 & 3.46 & 7.59 & 33.65 \\
\hline South Africa & $1 / 47-12 / 95$ & 6.25 & -1.62 & 2.02 & 7.99 \\
\hline \multicolumn{6}{|c|}{ All 39 countries } \\
\hline Mean & & & -0.28 & 2.79 & \\
\hline Median & & & 1.49 & 3.63 & \\
\hline \multicolumn{6}{|c|}{14 countries with continuous histories into the $1920 \mathrm{~s}$} \\
\hline Mean & & & 1.51 & 4.62 & \\
\hline Median & & & 2.13 & 5.06 & \\
\hline
\end{tabular}

Note: + indicates a discontinuity in the series. 
Table 2

Return and Risk of Global Equity Markets

Arithmetic Return in Percent per Annum

\begin{tabular}{|c|c|c|c|c|}
\hline Country & Period & $\begin{array}{l}\text { Hominal Return } \\
\text { Averag* (S.D.) }\end{array}$ & $\begin{array}{l}\text { Real } \\
\text { Average }\end{array}$ & $\begin{array}{l}\text { Return } \\
\text { (S.D.) }\end{array}$ \\
\hline U.S. & $1 / 21-12 / 95$ & $8.54 * *(16.85)$ & \multicolumn{2}{|c|}{$5.98 * *(16.53)$} \\
\hline Canada & $1 / 21-12 / 95$ & $6.81 * *(16.87)$ & $4.13 *$ & $(16.66)$ \\
\hline Austria & $1 / 25-12 / 95$ & $6.96 * *(19.05)$ & 3.16 & $(19.63)$ \\
\hline Belgium & $1 / 21-12 / 95$ & $6.15 * *(18.01)$ & 1.23 & $(19.07)$ \\
\hline Denmark & $1 / 26-12 / 95$ & $6.11 * *(12.08)$ & $2.2 \theta$ & $(12.73)$ \\
\hline Finland & $1 / 31-12 / 95$ & $11.07 * *(16.30)$ & 3.31 & $(16.70)$ \\
\hline France & $1 / 21-12 / 95$ & $10.64 * *(21.43)$ & 2.54 & $(21.19)$ \\
\hline Germany+ & $1 / 24-7 / 44$ & $3.30 \quad(22.00)$ & 3.63 & $(17.26)$ \\
\hline Germany+ & $1 / 50-12 / 95$ & $9.20 * *(15.61)$ & \multicolumn{2}{|c|}{$6.83 * *(15.71)$} \\
\hline Ireland & $1 / 34-12 / 95$ & $7.68 * *(14.93)$ & 2.28 & $(15.09)$ \\
\hline Italy & $1 / 28-12 / 95$ & $12.62 * *(26.01)$ & 3.15 & $(25.66)$ \\
\hline Netherlands & $1 / 21-12 / 95$ & $5.24 * *(15.30)$ & 3.06 & $(14.80)$ \\
\hline Norway & $1 / 28-12 / 95$ & $8.66 * *(20.27)$ & 4.61 & $(20.24)$ \\
\hline Portugalt & $12 / 30-4 / 74$ & $6.50 * *(15.15)$ & 2.34 & $(14.69)$ \\
\hline Portugalt & $1 / 82-12 / 95$ & $23.96 * *(39.49)$ & 13.11 & $(40.74)$ \\
\hline Spain & $1 / 21-12 / 95$ & $5.42 * *(15.09)$ & -1.03 & $(15.39)$ \\
\hline Sweden & $1 / 21-12 / 95$ & $8.22 * *(16.65)$ & \multicolumn{2}{|c|}{$5.04 * *(16.61)$} \\
\hline Sitzerland & $1 / 26-12 / 95$ & $5.68 * *(14.82)$ & \multicolumn{2}{|c|}{$4.08 *(14.77)$} \\
\hline UK & $1 / 21-12 / 95$ & $7.27 *(15.51)$ & 3.50 & (15.79) \\
\hline Czechoslovakia & $1 / 21-6 / 43$ & $3.82 * *(15.64)$ & \multicolumn{2}{|c|}{$5.20 *(13.42)$} \\
\hline Greece & $7 / 29-9 / 40$ & $-0.09 \quad(21.77)$ & -3.44 & $(21.61)$ \\
\hline Hungary & $1 / 25-6 / 44$ & $(25.84)$ & 6.20 & $(26.58)$ \\
\hline Poland & $1 / 21-6 / 39$ & $13.60 \quad(71.20)$ & 14.40 & $(65.69)$ \\
\hline Romania & $12 / 37-6 / 41$ & $0.14 \quad(33.31)$ & -27.30 & $(31.38)$ \\
\hline Australia & $1 / 31-12 / 95$ & $7.79 * *(13.56)$ & 2.50 & $(14.02)$ \\
\hline Nev Zealand & $1 / 25-12 / 95$ & $6.16 * *(12.16)$ & 0.33 & $(12.54)$ \\
\hline Japant & $1 / 21-5 / 44$ & $2.72 \quad(17.51)$ & 0.89 & $(15.79)$ \\
\hline Japant & $4 / 49-12 / 95$ & $10.11 * *(18.89)$ & \multicolumn{2}{|c|}{$7.49 * *(19.01)$} \\
\hline India & $1 / 40-12 / 95$ & $6.32 * *(15.48)$ & -0.94 & $(15.89)$ \\
\hline Pakistan & $7 / 60-12 / 95$ & $8.50 * *(14.03)$ & -0.13 & $(14.86)$ \\
\hline Philippines & $7 / 54-12 / 95$ & $10.41 * *(37.69)$ & 0.84 & $(37.57)$ \\
\hline
\end{tabular}


Table 2

(continued)

\begin{tabular}{|c|c|c|c|c|}
\hline Argentinat & $9 / 47-7 / 65$ & $-1.13 \quad(31.91)$ & -23.32 & $(32.73)$ \\
\hline Argentinat & $12 / 75-12 / 95$ & $187.25(136.33)$ & 51.29 & $(89.78)$ \\
\hline Brazil & $2 / 61-12 / 95$ & $112.86 \quad(69.03)$ & 12.51 & $(52.58)$ \\
\hline Mexico & $12 / 34-12 / 95$ & $21.99 * *(26.99)$ & 5.51 & $(24.55)$ \\
\hline Chilet & $1 / 27-3 / 71$ & $14.51 * *(22.45)$ & -3.33 & $(20.51)$ \\
\hline Chilet & $12 / 73-12 / 95$ & $52.86 * *(40.54)$ & 14.49 & (38.83) \\
\hline Colombia & $12 / 36-12 / 95$ & $11.65 * *(21.64)$ & -2.34 & $(21.87)$ \\
\hline Perut & $3 / 41-1 / 53$ & $3.07 \quad(13.01)$ & $-11.35 * *$ & $(13.95)$ \\
\hline Perut & $1 / 57-12 / 77$ & $2.22 \quad(10.24)$ & $-9.66 * *$ & $(10.21)$ \\
\hline Perut & $12 / 88-12 / 95$ & $227.08 \quad(124.6)$ & 62.86 & $(95.67)$ \\
\hline Uruguay & $12 / 36-11 / 44$ & $10.26 \quad(19.29)$ & 6.81 & $(30.16)$ \\
\hline Venezuela & $12 / 37-12 / 95$ & $10.26 * *(24.03)$ & 0.21 & $(24.42)$ \\
\hline Egypt $_{\text {gyp }}$ & $7 / 50-9 / 62$ & $-0.83 \quad(11.50)$ & -2.11 & $(12.54)$ \\
\hline Israel & $1 / 57-12 / 95$ & $36.13 * *(26.20)$ & 6.12 & $(23.08)$ \\
\hline South Africa & $1 / 47-12 / 95$ & $7.37 * *(15.83)$ & -0.31 & $(15.92)$ \\
\hline
\end{tabular}


Table 3

Comparison of Real Returns with and vithout Dividends

\begin{tabular}{|c|c|c|c|c|c|}
\hline \multicolumn{3}{|c|}{$\begin{array}{r}\text { Compound } \\
\text { Return } \\
\text { vith }\end{array}$} & $\begin{array}{r}\text { Compound } \\
\text { Return } \\
\text { vithout } \\
\text { Dividend } \\
(\% \text { pa) }\end{array}$ & $\begin{array}{r}\text { Difference } \\
\text { due to } \\
\text { Dividend }\end{array}$ & Inflation \\
\hline \multicolumn{6}{|c|}{ Markets Covered by MSCIP, 1970-1995 } \\
\hline Austr & alia & 3.65 & -0.71 & 4.36 & 6.79 \\
\hline Austr & & 4.89 & 2.07 & 2.82 & 2.75 \\
\hline Belgil & & 12.97 & 4.05 & 8.92 & 2.46 \\
\hline Canad: & & 4.34 & 0.65 & 3.69 & 5.78 \\
\hline Denmaj & & 6.54 & 2.71 & 3.83 & 5.62 \\
\hline Franc & & 4.45 & -0.29 & 4.74 & 7.40 \\
\hline Germar & & 5.52 & 1.44 & 4.08 & 3.09 \\
\hline Italy & & -0.26 & -2.95 & 2.69 & 9.87 \\
\hline Japan & & 8.59 & 6.75 & 1.84 & 2.18 \\
\hline Nethel & rlands & 8.84 & 3.09 & 5.74 & 3.41 \\
\hline Norway & & 6.03 & 2.78 & 3.26 & 5.90 \\
\hline Spain & & 2.30 & -4.00 & 6.31 & 8.40 \\
\hline Sweder & & 8.79 & 5.03 & 3.76 & 7.42 \\
\hline Switz & erland & 5.72 & 3.06 & 2.66 & 2.54 \\
\hline UK & & 6.39 & 1.23 & 5.16 & 8.35 \\
\hline USA & & 6.15 & 2.01 & 4.14 & 4.89 \\
\hline Averas & & 5.93 & 1.68 & 4.25 & 5.43 \\
\hline \multicolumn{6}{|c|}{ Long-Term Markets } \\
\hline Denmark, & $1923-9 \dot{5}$ & 4.88 & 0.64 & 4.24 & 3.72 \\
\hline Sweden, & $1926-95$ & 7.13 & 3.30 & 3.83 & 3.64 \\
\hline Switz., & $1921-95$ & 5.57 & 2.12 & 3.45 & 2.49 \\
\hline UK, & $1921-95$ & 8.16 & 2.99 & 5.17 & 3.75 \\
\hline USA, & $1921-95$ & 8.22 & 3.38 & 4.84 & 2.69 \\
\hline
\end{tabular}

Hote: For the Morgan Stanley Capital International Perspective (HSCIP) indices, the compound real returns are measured by deflating by the tholesale Price Index. The other long-term series are obtained from various sources, which all report the Consumer Price Index, except for Denmark, for which the WPI is used. 
Table 4

Analysis of Stock Prices around Breaks

All Returns Deflated by WPI

\begin{tabular}{|c|c|c|c|c|c|}
\hline Country & $\begin{array}{r}\text { Break } \\
\text { date }\end{array}$ & $\begin{array}{r}\text { Previous } \\
\text { year } \\
\text { return }\end{array}$ & $\begin{array}{r}\text { Series } \\
\text { restart } \\
\text { date }\end{array}$ & $\begin{array}{l}\text { chabsequent } \\
\text { change }\end{array}$ & Comment \\
\hline Hungary & $7 / 31$ & -0.222 & $9 / 32$ & 0.125 & Financial crisis, country in defaul \\
\hline Germany & $7 / 31$ & -0.316 & $4 / 32$ & -0.232 & Credit crisis \\
\hline Greece & $10 / 31$ & -0.099 & $12 / 32$ & -0.581 & Financial crisis, drought \\
\hline Spain & $7 / 36$ & -0.113 & $3 / 40$ & -0.147 & Civil War \\
\hline Austria & $4 / 38$ & -0.179 & $12 / 46$ & 0.941 & Annexation by Germany \\
\hline Czechoslovakia & $10 / 38$ & -0.205 & $1 / 40$ & 0.015 & Session of land to Germany \\
\hline Poland & $7 / 39$ & 0.169 & & & Invaded by Germany (Sep 30) \\
\hline Finland & $12 / 39$ & -0.192 & $3 / 40$ & -0.101 & Invaded by Soviets (Nov 30) \\
\hline Denmark & $4 / 40$ & -0.328 & $6 / 40$ & -0.084 & Invaded by Germany (Apr 9) \\
\hline Norway & $4 / 40$ & -0.274 & $6 / 40$ & -0.154 & Invaded by Germany (Apr 11) \\
\hline Netherlands & $5 / 40$ & -0.231 & $9 / 40$ & 0.105 & Invaded by Germany (May 10) \\
\hline Belgium & $5 / 40$ & -0.267 & $12 / 40$ & 0.850 & Invaded by Germany (May 10) \\
\hline Switzerland & $5 / 40$ & -0.193 & $7 / 40$ & -0.207 & Mobilization \\
\hline France & $6 / 40$ & -0.122 & $4 / 41$ & 0.824 & Invaded by Germany (Jun 14) \\
\hline Greece & $10 / 40$ & -0.249 & & & Invaded by Germany (Oct 28) \\
\hline Romania & $7 / 41$ & -0.396 & & & Enters war \\
\hline Czechoslovakia* & * $7 / 43$ & -0.141 & & & War ending \\
\hline Japan* & $6 / 44$ & -0.211 & & & War ending \\
\hline Hungary* & $7 / 44$ & -0.491 & & & War turmoil? \\
\hline Belgium* & $8 / 44$ & 0.161 & $6 / 45$ & -0.145 & War turmoil? \\
\hline Germany* & $8 / 44$ & -0.013 & & & Invaded by Allied (Sep 15) \\
\hline Egypt & $10 / 62$ & -0.126 & & & Arab socialism \\
\hline Argentina & $8 / 65$ & -0.692 & & & Widespread unrest \\
\hline Chile & $4 / 71$ & -0.543 & & & State takes control of economy \\
\hline Portugal & $4 / 74$ & -0.112 & $3 / 77$ & -0.860 & Takeover by junta (Apr 27) \\
\hline
\end{tabular}

Note: * indicates that equities were effectively subject to price controls. For Portugal, the index was observed right after the break, but does not continue thereafter. 
Table 5

Relative Importance of Economies

Percentage Weights Based on U.S. Dollar Prices

\begin{tabular}{|c|c|c|c|c|}
\hline \multirow[t]{2}{*}{ Country } & \multicolumn{3}{|c|}{ GDP Weights } & \multirow{2}{*}{$\begin{array}{c}\text { Market } \\
\text { Capitalization } \\
1995\end{array}$} \\
\hline & 1920 & 1950 & 1990 & \\
\hline-------- & ------ & ------ & ---------- & \\
\hline U.S. & $46.17 \%$ & $51.52 \%$ & $30.59 \%$ & $41.03 \%$ \\
\hline Canada & $2.40 \%$ & $3.16 \%$ & $3.17 \%$ & $2.16 \%$ \\
\hline Austria & $0.48 \%$ & $0.47 \%$ & $0.87 \%$ & $0.24 \%$ \\
\hline Belgium & $0.73 \%$ & $1.27 \%$ & $1.09 \%$ & $0.66 \%$ \\
\hline Denmark & $0.55 \%$ & $0.56 \%$ & $0.72 \%$ & $0.37 \%$ \\
\hline Finland & $0.17 \%$ & $0.42 \%$ & $0.76 \%$ & $0.26 \%$ \\
\hline France & $6.14 \%$ & $5.19 \%$ & $6.61 \%$ & $3.27 \%$ \\
\hline Germany & $6.04 \%$ & $4.19 \%$ & $8.29 \%$ & $3.75 \%$ \\
\hline Ireland & $0.42 \%$ & $0.19 \%$ & $0.24 \%$ & $0.16 \%$ \\
\hline Italy & $1.67 \%$ & $2.43 \%$ & $6.07 \%$ & $1.16 \%$ \\
\hline Netherlands & $0.98 \%$ & $0.89 \%$ & $1.57 \%$ & $1.97 \%$ \\
\hline Norway & $0.56 \%$ & $0.38 \%$ & $0.59 \%$ & $0.28 \%$ \\
\hline Portugal & $0.62 \%$ & $0.25 \%$ & $0.33 \%$ & $0.12 \%$ \\
\hline Spain & $2.16 \%$ & $0.82 \%$ & $2.72 \%$ & $0.99 \%$ \\
\hline Sweden & $1.22 \%$ & $1.11 \%$ & $1.26 \%$ & $1.14 \%$ \\
\hline Suitzerland & $0.84 \%$ & $0.80 \%$ & $1.25 \%$ & $2.60 \%$ \\
\hline UK & $10.36 \%$ & $6.57 \%$ & $5.41 \%$ & $8.77 \%$ \\
\hline Czechoslovakia & $0.52 \%$ & $0.31 \%$ & $0.25 \%$ & $0.10 \%$ \\
\hline Greece & $0.33 \%$ & $0.39 \%$ & $0.37 \%$ & $0.11 \%$ \\
\hline Bungary & $0.38 \%$ & $0.71 \%$ & $0.18 \%$ & $0.02 \%$ \\
\hline Poland & & $1.82 \%$ & $0.35 \%$ & $0.03 \%$ \\
\hline Romania & & $0.00 \%$ & $0.21 \%$ & - \\
\hline Australia & $2.31 \%$ & $1.07 \%$ & $1.63 \%$ & $1.59 \%$ \\
\hline Her Zealand & $0.15 \%$ & $0.35 \%$ & $0.24 \%$ & $0.21 \%$ \\
\hline Japan & $4.06 \%$ & $1.96 \%$ & $16.24 \%$ & $23.19 \%$ \\
\hline India & $6.92 \%$ & $3.54 \%$ & $1.68 \%$ & $0.82 \%$ \\
\hline Pakistan & & $0.67 \%$ & $0.22 \%$ & $0.06 \%$ \\
\hline Philippines & & $0.63 \%$ & $0.24 \%$ & $0.38 \%$ \\
\hline Argentina & $1.20 \%$ & $0.90 \%$ & $0.78 \%$ & $0.24 \%$ \\
\hline Brazil & $0.75 \%$ & $2.84 \%$ & $2.66 \%$ & $0.96 \%$ \\
\hline Mexico & $0.66 \%$ & $0.85 \%$ & $1.34 \%$ & $0.59 \%$ \\
\hline Chile & $0.19 \%$ & $0.75 \%$ & $0.15 \%$ & $0.48 \%$ \\
\hline Colombia & & $0.72 \%$ & $0.22 \%$ & $0.12 \%$ \\
\hline Peru & & $0.19 \%$ & $0.20 \%$ & $0.08 \%$ \\
\hline Uruguay & & $0.18 \%$ & $0.05 \%$ & $0.00 \%$ \\
\hline Venezuela & & $0.57 \%$ & $0.27 \%$ & $0.02 \%$ \\
\hline Egypt & & $0.45 \%$ & $0.31 \%$ & $0.05 \%$ \\
\hline Israel & & $0.24 \%$ & $0.29 \%$ & $0.24 \%$ \\
\hline South Africa & $1.03 \%$ & $0.65 \%$ & $0.56 \%$ & $1.82 \%$ \\
\hline \multicolumn{5}{|l|}{ Memorandum: } \\
\hline GDP (millions) & $\$ 198,177$ & $\$ 556,495$ & $\$ 18,049,738$ & \\
\hline Market cap (m) & & & & $\$ 15,448,900$ \\
\hline
\end{tabular}


Table 6

Performance of Global Stock Index: 1921-1995

Real Returns (Percent Per Annum)

$\begin{array}{lccc}\text { Index } & \begin{array}{c}\text { Arithmetic } \\ \text { Return }\end{array} & \begin{array}{l}\text { Volatility } \\ \text { U.S. Index }\end{array} & \begin{array}{c}\text { Compound } \\ \text { Return }\end{array} \\ & 5.98 & 16.53 & 4.73 \\ \text { Global Index: } & & & \\ \text { - survived markets } & 5.37 & 12.81 & 4.65 \\ \text { - continuous markets } & 4.86 & 11.23 & 4.31 \\ \text { - reconstructed markets } & 4.74 & 11.25 & 4.18 \\ & & & \\ \text { Non-U.S. Index } & 4.17 & 9.60 & 3.77 \\ \text { - survived markets } & 3.51 & 8.95 & 3.15 \\ \text { - continuous markets } & 3.29 & 9.01 & 2.92 \\ \text { - reconstructed markets } & & & \\ \text { - } & & & \end{array}$

Table 7

Performance of Global Stock Index: 1921-1995 Nominal Returns in U.S. Dollars (Percent Per Annum)

Arithmetic
Return $\quad$ Volatility $\quad \begin{gathered}\text { Compound } \\ \text { Return }\end{gathered}$

U.S. Index

8.54

16.84

7.37

Global Index:

- survived markets

8.48

13.85

7.80

- continuous markets

8.09

12.39

7.58

- reconstructed markets

7.96

12.41

7.44

Non-U.S. Index

- survived markets

- continuous markets

7.60

7.23

11.69

11.23

6.99

11.27

7.14

6.80

- reconstructed markets

6.54 


\section{Fig.1. Real Returns on Global Stock Markets}

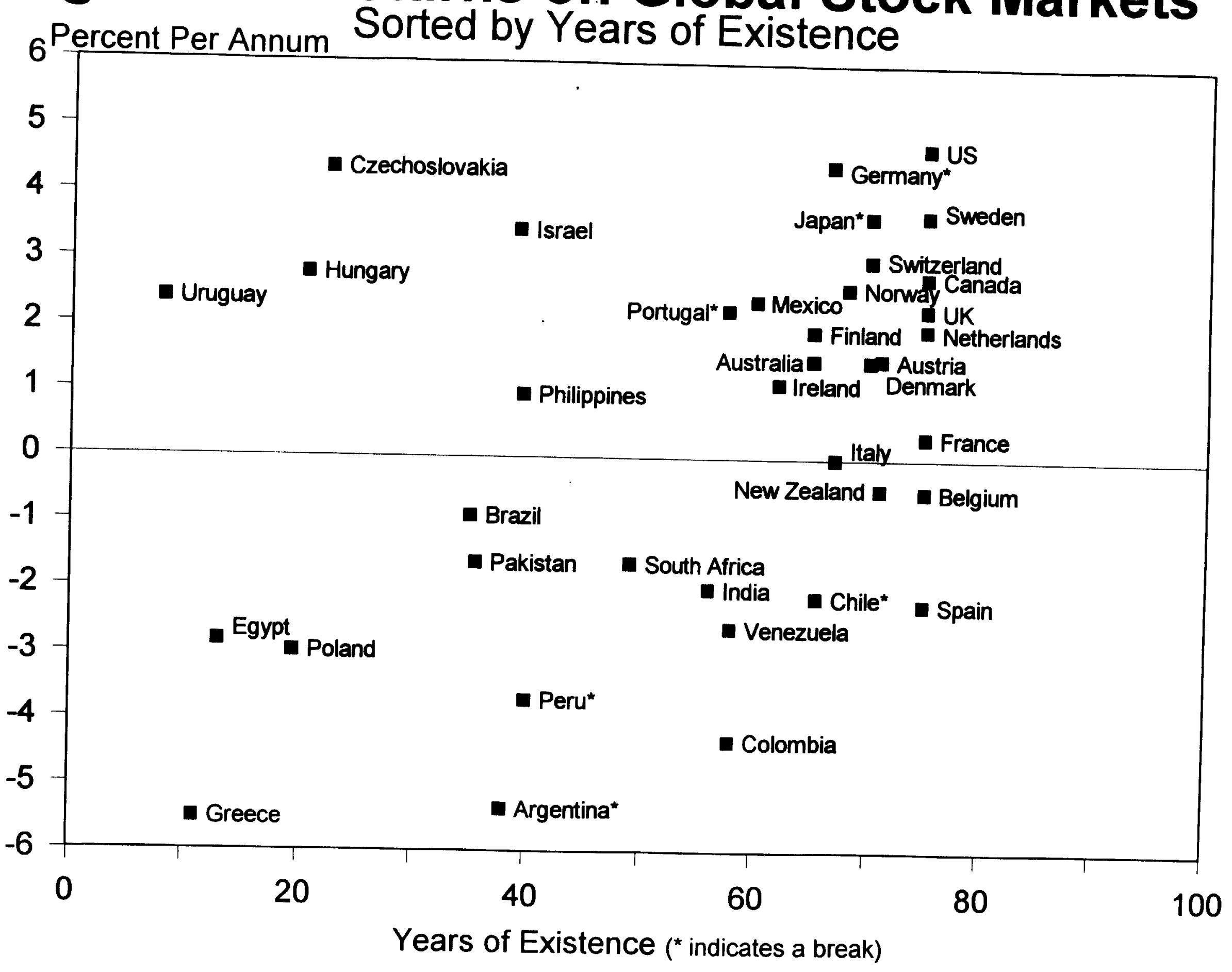


Fig.2. Real Stock Prices before Interruption

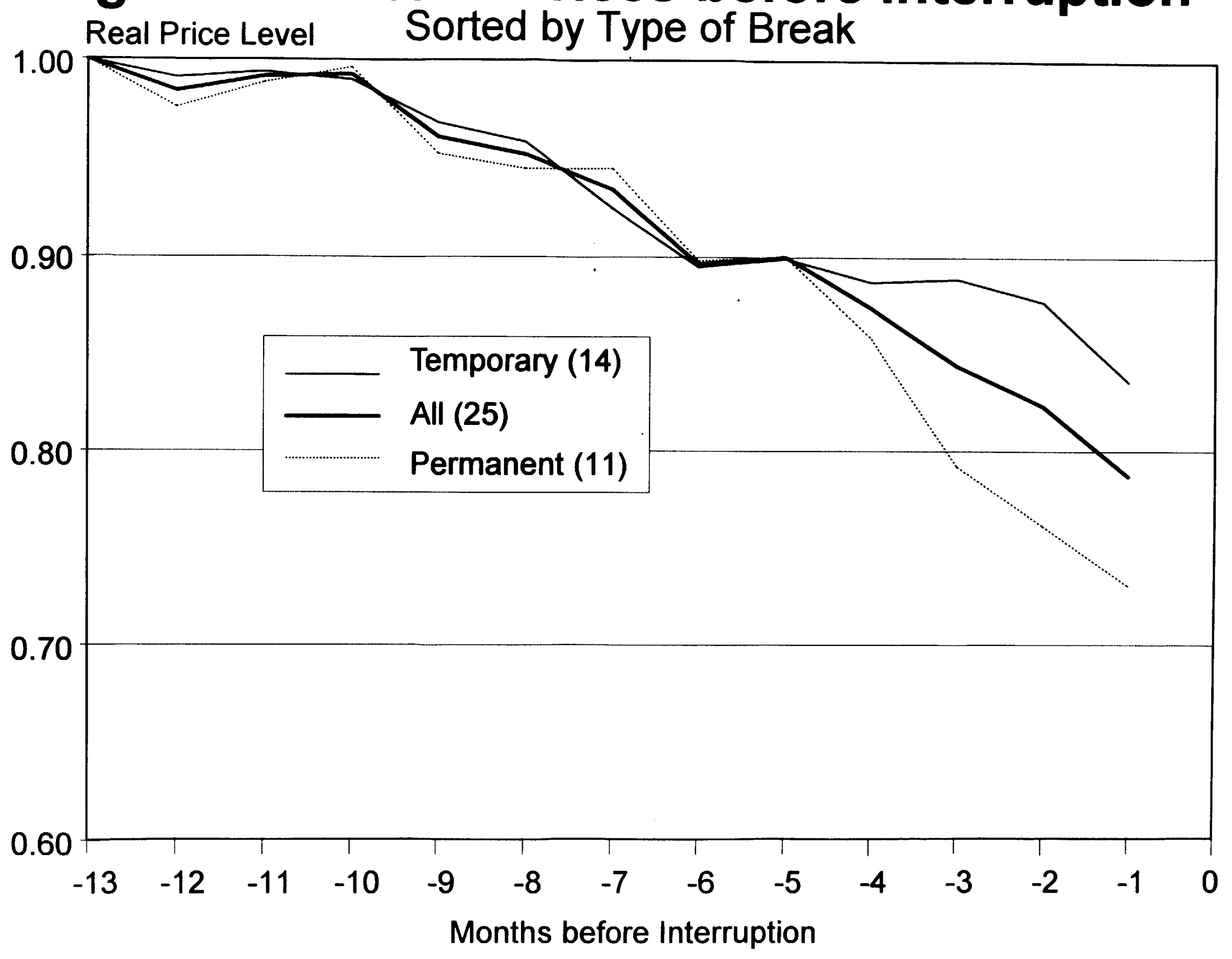




\section{Fig.3. Real Stock Prices during World War II}

\section{Real Price Level}

Sorted by Country Involvement

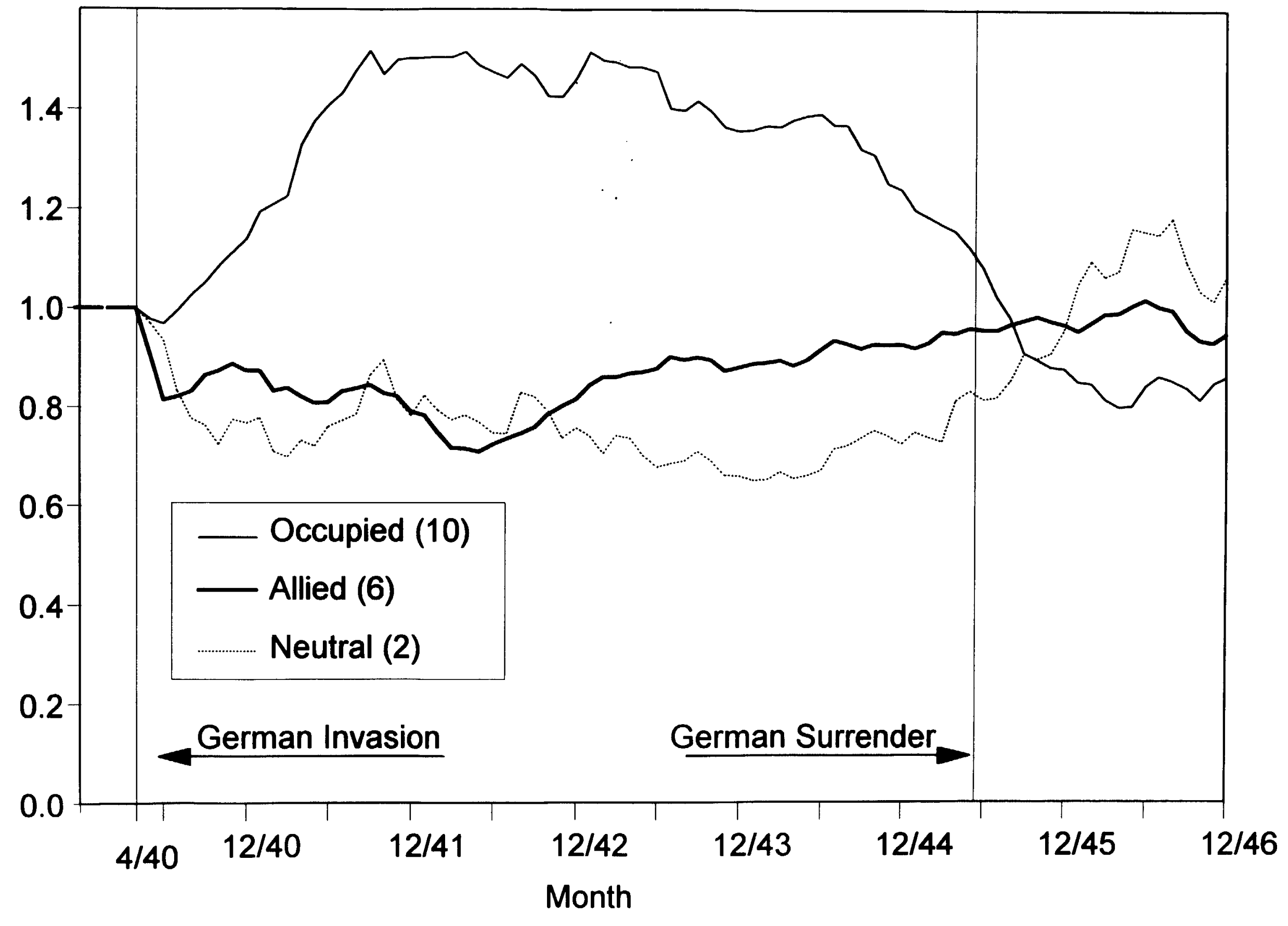




\section{Fig.4. A Global Stock Market Index 1921-1995}

Real Terms

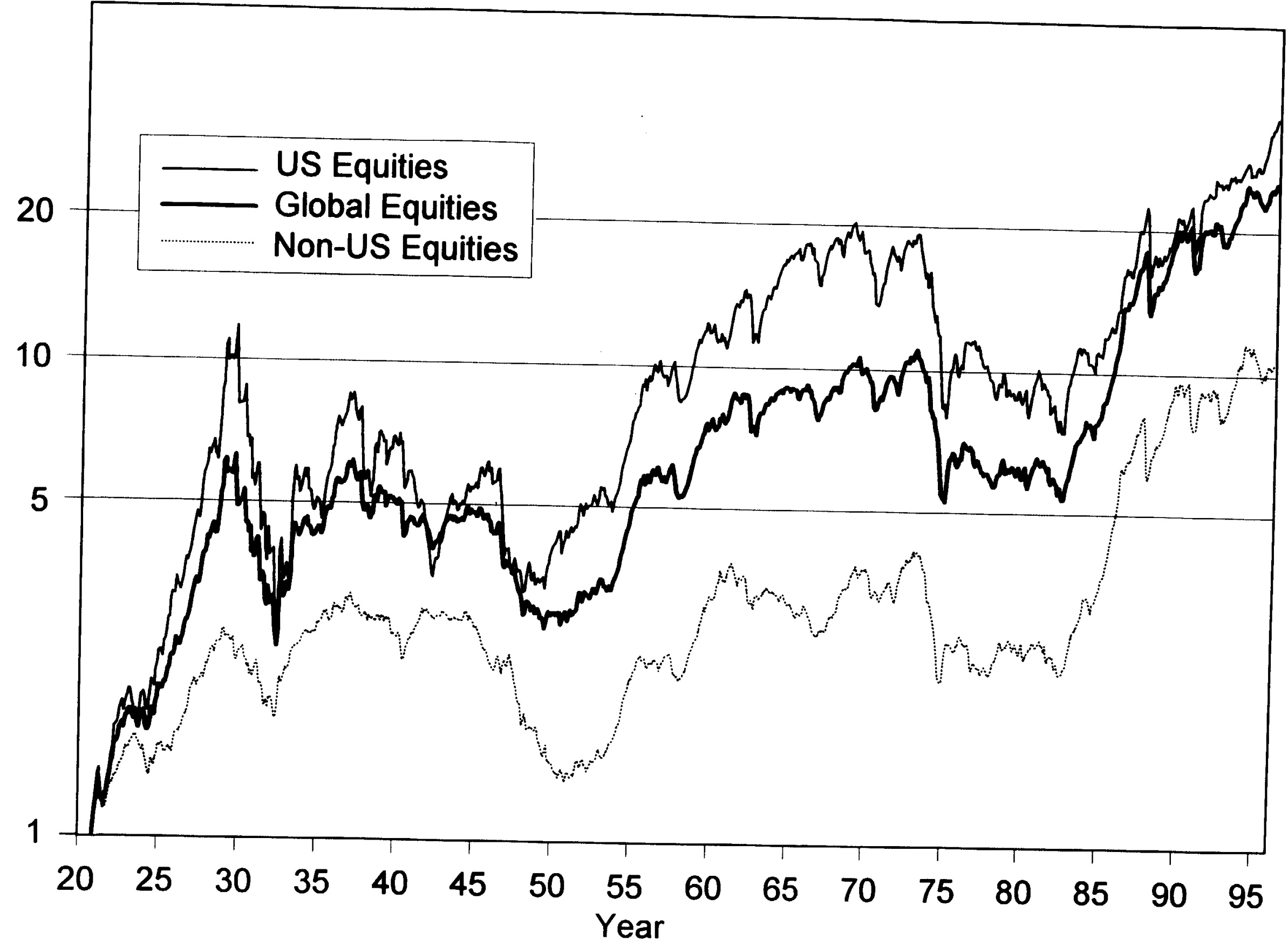

